\title{
Top-down mass spectrometry reveals multiple interactions of an acetylsalicylic acid bearing Zeise's salt derivative with peptides
}

\author{
Monika Cziferszky ${ }^{1} \cdot$ Ronald Gust $^{1}$ (D)
}

Received: 3 December 2019 / Accepted: 24 January 2020 / Published online: 14 February 2020

(c) The Author(s) 2020

\begin{abstract}
Synergistic effects and promising anticancer activities encourage the combination of non-steroidal anti-inflammatory drugs with metallodrugs. Here, we discuss the interactions of an organometallic complex consisting of an acetylsalicylic acid (ASA) moiety attached to a $\mathrm{Pt}^{\mathrm{II}}$ center via an alkenol linker in a Zeise's salt-type coordination (ASA-buten-PtCl ${ }_{3}$ ) with model peptides angiotensin 1 (AT), substance P (Sub P), and ubiquitin (UQ). Top-down mass spectrometry experiments show that the amino acid involved in the initial binding to the metal complex controls the coordination sphere of $\mathrm{Pt}^{\mathrm{II}}$ in the adducts. The strong trans labilizing effect of the coordinating sulfur atom in Met causes fast release of the organic moiety and leads to the formation of dimers and oligomers in the case of Sub P. In contrast, interactions with nitrogen donors in AT result in stable adducts containing the intact ASA-buten- $\mathrm{Pt}^{\mathrm{II}}$ complex. UQ forms two sets of $\mathrm{Pt}^{\mathrm{II}}$ adducts, only one of them retains the ASA moiety, which is presumably the result of an unexpected binding geometry. Importantly, UQ is additionally acetylated at various Ser and Lys residues by the ASA-buten- $\mathrm{PtCl}_{3}$ complex. Control experiments with ASA are negative. This is the first example of concomitant platination and acetylation of a peptide with an ASA metal complex.
\end{abstract}

Keywords Metallodrug $\cdot$ Anticancer drug $\cdot$ Binding site identification $\cdot$ Peptide $\cdot$ Zeise's salt $\cdot$ Acetylation

\section{Introduction}

In the quest for novel anticancer agents, the combination of metallodrugs with biologically active compounds is gaining momentum. In particular, metal complexes of non-steroidal anti-inflammatory drugs (NSAIDs) show synergistic effects and promising anticancer activities. A recent review [1] discusses a vast number of metal complexes of NSAIDs and their antibacterial, antifungal, and antiproliferative activities as well as DNA-binding properties, highlighting the advantages and possibilities of these drug candidates. NSAIDs are a group of well-known medications for the treatment

Electronic supplementary material The online version of this article (https://doi.org/10.1007/s00775-020-01760-9) contains supplementary material, which is available to authorized users.

\section{Ronald Gust}

ronald.gust@uibk.ac.at

1 Department of Pharmaceutical Chemistry, CMBI-Center for Molecular Biosciences, CCB-Centrum for Chemistry and Biomedicine, Innsbruck, Institute of Pharmacy, University of Innsbruck, Innrain 80-82, 6020 Innsbruck, Austria of inflammation, pain, and fever, with acetylsalicylic acid (ASA, marketed as Aspirin by Bayer) being a famous example that was already synthesized more than 100 years ago. It exhibits its anti-inflammatory and analgesic effect through acetylation of Ser residues in the active site of cyclooxygenase enzymes (Ser529 in COX-1 and Ser516 in COX-2), which causes irreversible inhibition [2]. All other NSAIDs inhibit COX metabolism through reversible non-covalent attachment to the active site [2]. Today, NSAIDs cover a large number of compounds classified according to their chemical structure, including salicylic acid derivatives, oxicams, sulfonamides, and others.

Overexpression of COX-2 in different types of tumors, such as prostate, colon, or breast cancer, makes this enzyme an interesting target for the development of novel anticancer drug candidates. Most NSAIDs non-selectively inhibit both COX enzymes. Only a few specific COX-2 inhibitors are on the market. Coordination of NSAIDs to metal centers aims at obtaining antiproliferative activity through a dual mode of action: inhibition of COX and, e.g., ROS generation by the metal. Complexes of $\mathrm{Ru}^{\mathrm{II}}, \mathrm{Os}^{\mathrm{II}}, \mathrm{Cu}^{\mathrm{II}}, \mathrm{Re}^{\mathrm{II}}, \mathrm{Fe}^{\mathrm{II}}, \mathrm{Co}^{\mathrm{II}}$ and $\mathrm{Zn}^{\mathrm{II}}$ with indomethacin, naproxen, diclofenac and ibuprofen have been reported [3-11]. Examples of ASA derivatives involve 
$\mathrm{Ir}^{\mathrm{III}}$ [12], $\mathrm{Pt}^{\mathrm{IV}}$ [13], $\mathrm{Ag}^{\mathrm{I}}[14,15]$ and various metal carbonyls [16-18]. Most recently, the ASA moiety was linked to $\mathrm{Pt}^{\mathrm{II}}$ via an alkenol spacer in a Zeise's salt-type coordination [19], and the influence of the spacer length on the stability and bioactivity of the compounds was determined in our group [20]. In the present study, we chose the most promising candidate ASA-buten- $\mathrm{PtCl}_{3}$ (see Fig. 1) to gain an in-depth understanding of the molecular interactions of this type of compound with peptides.

Mass spectrometry (MS) is a powerful analytical tool to study the adduct formation of metallodrugs with biomolecules on account of its sensitivity and ability to cope with complex mixtures. The possibility to isolate any gaseous ion of interest, including low abundant species, and dissociate them via an array of different fragmentation techniques (MS/MS) enables in-depth structural analysis of these adducts. Ion dissociation techniques are either based on collisions (collision-induced dissociation CID, higherenergy collisional dissociation HCD) or the transfer/capture of electrons (electron capture dissociation ECD, electron transfer dissociation ETD, and electron detachment dissociation EDD) or the absorption of photons (infrared multiphoton dissociation IRMPD, blackbody infrared radiative dissociation BIRD, and ultraviolet photodissociation UVPD). In the context of metallodrug research, ETD has been reported to perform better than CID and HCD for $\mathrm{Pt}^{\mathrm{II}}$ peptide adducts [21], while ECD proved to be challenging for $\mathrm{Ir}^{\mathrm{III}}$ peptide adducts due to electron quenching, yet it was successfully used to determine the modification sites [22]. Photodissociation methods have shown promising results for pinpointing cisplatin-binding sites on oligonucleotides [23]. Various MS-based approaches including high-resolution top-down MS, bottom-up methods, and ion-mobility MS are pursued to obtain information about novel metal compounds in a biological and medicinal setting, and ultimately to understand their mode of action [24, 25]. Top-down methodologies are particularly interesting, as little sample preparation is required and, consequently, the danger of further alterations of the newly formed

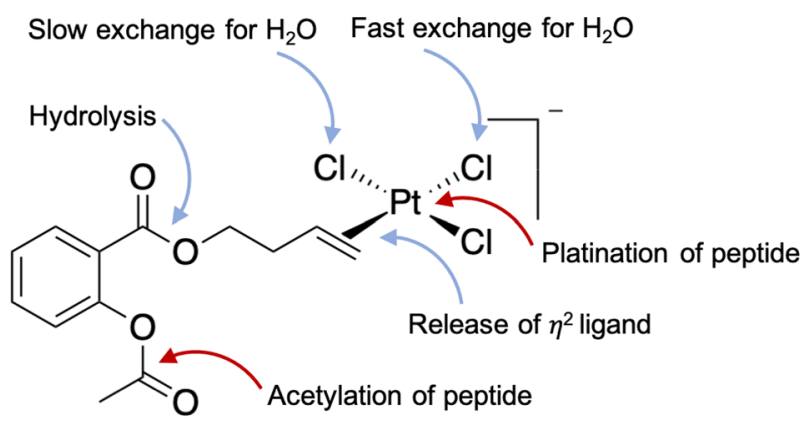

Fig. 1 Possible reactions of ASA-buten- $\mathrm{PtCl}_{3}$ with peptides in aqueous solutions metal-biomolecule bond is minimized. The unambiguous determination of metallation sites for $\mathrm{Pt}^{\mathrm{II}}, \mathrm{Ru}^{\mathrm{II}}$, $\mathrm{Ir}^{\mathrm{III}}$, and $\mathrm{Os}^{\mathrm{II}}$ compounds on various peptides [26-28], proteins [29, 30], and oligonucleotides [31-33] was achieved through top-down MS.

Cisplatin is a potent anticancer drug, which exerts its mode of action through binding to two adjacent N7 in guanine residues of DNA [34]. However, up to $98 \%$ of cisplatin in the blood plasma is protein-bound within 1 day of injection [35]. While protein binding may serve as transport mechanism, the high reactivity of $\mathrm{Pt}^{\mathrm{II}}$ complexes with enzymes is likely a primary cause for the large number of dose-limiting side effects of $\mathrm{Pt}^{\mathrm{II}}$-based chemotherapy [36]. Sulfur-containing Met and Cys as well as the nitrogen donor His are generally accepted binding partners for cisplatin and other $\mathrm{Pt}^{\mathrm{II}}$ compounds [37-43]. While thiols and thioethers rapidly displace chlorido ligands on cisplatin directly, reactions with amines require a rate-determining aquation step first [44].

In the current study, we seek to get a better understanding of the molecular interactions of ASA-buten- $\mathrm{PtCl}_{3}$ with three different model peptides as reaction partners. Angiotensin I (AT) is a ten-amino acid peptide hormone containing two His residues as possible metallation sites. Substance $\mathrm{P}$ (Sub $\mathrm{P})$, an eleven-amino acid neurotransmitter, contains a C-terminal Met amide. And ubiquitin (UQ) consists of 76 amino acids with an N-terminal Met and one His at position 68 . The sequences of the three peptides are depicted in Fig. 3. An MS-based study on the reaction products of Zeise's salt with AT and UQ was published recently by our group [45], where we demonstrated that trans labilizing effects play a crucial role in the overall peptide metallation by $\mathrm{Pt}^{\mathrm{II}}$ complexes. Replacement of the ethylene ligand in Zeise's salt with an ASA-buten moiety led to remarkable COX inhibition (three times higher than ASA alone) and antiproliferative activity $\left(\mathrm{IC}_{50} \sim 30 \mu \mathrm{M}\right.$ in HT-29 and MCF-7 cell lines) [20]. Here, we shine light on the underlying molecular interactions. A particularly interesting question is, if this type of ASA derivative retains its potential to acetylate susceptible amino acids. Few studies have addressed this question so far. Hey-Hawkins et al. reported acetylation of COX-1 and COX-2 at various peripheral Lys and Ser residues by asborin, a carbaborane with ASA-like features. However, no acetylation was found in the active sites of both COX enzymes [46]. Similarly, a $\mathrm{Co}^{0}$-carbonyl ASA complex of our group did not acetylate Ser516 in COX-2 but rather acetylated a number of Lys residues [18]. Another example for the successful combination of an alkylating agent with a metal compound is the chlorambucil-functionalized $\mathrm{Ru}^{\mathrm{II}}$ complex of Nazarov et al. [47] designed to crosslink DNA with proteins by interactions of the metal with amino acids and simultaneous alkylation of N7 in guanine. 


\section{Experimental}

\section{Chemicals and reagents}

Angiotensin I (human, acetate salt hydrate, $>90 \%$ ), ubiquitin (from bovine erythrocytes, > 98\%), and substance $\mathrm{P}$ (acetate salt hydrate, $>95 \%$ ) were obtained from Sigma-Aldrich and used as received. Solvents were purchased in MS quality from Sigma-Aldrich. Synthesis, stability and biological data of ASA-buten-PtCl ${ }_{3}$ are reported elsewhere [20].

\section{Incubation}

Peptides $(10 \mu \mathrm{M})$ were incubated with ASA-buten- $\mathrm{PtCl}_{3}$ in 1:5 ratio in pure water at $37^{\circ} \mathrm{C}$. Aliquots were taken after $5 \mathrm{~min}, 2 \mathrm{~h}, 24 \mathrm{~h}$, and $48 \mathrm{~h}$, diluted with $0.1 \%$ formic acid in acetonitrile, and directly infused into the mass spectrometer as described below. A final measurement was performed after 7 days of incubation. In the case of UQ, samples were centrifuged on prewashed nanosep centrifugal devices with a molecular weight cut-off of $3500 \mathrm{Da}$ at $8500 \mathrm{rpm}$ and washed with water twice to remove any excess metal complex. Finally, the remaining peptide was diluted as described above and measured. All aqueous peptide solutions with ASA-buten- $\mathrm{PtCl}_{3}$ or ASA were at $\mathrm{pH} 6$, which corresponds roughly to the isoelectric point of UQ. The $\mathrm{pH}$ did not change over the course of the reaction.

\section{ESI-MS analysis}

Samples were measured on an Orbitrap Elite (Thermo Fisher Scientific) in positive mode under standard operating conditions using the HESI source (heated electrospray ionization) and the syringe pump. HCD experiments were performed manually on all ions of interest with an isolation window of 3-7 m/z. The normalized collision energy (NCE) was increased stepwise. Data were analyzed using Xcalibur software and the Apm² software tool developed by Dyson et al. [43] (https://ms.cheminfo.org/apm2s/index .html). Search parameters were as follows: common zone was set to "second", zone low -2.5 , high 4.5 , maximal length of internal fragments was set to 10 , and neutral loss was only ticked in the case of Sub P.

\section{Results and discussion}

The trans labilizing effect of all relevant ligands in this study increases in the order $\mathrm{H}_{2} \mathrm{O}<\mathrm{NR}_{3}<\mathrm{Cl}^{-}<\mathrm{SR}_{2}<\mathrm{CH}_{2}=\mathrm{CHR}$ [48]. In aqueous solution, the trans effect of ethylene in Zeise's salt causes aquation of the trans position in less than 2 min [49].

The stability of ASA-buten- $\mathrm{PtCl}_{3}$ was assessed in pure water and $0.9 \% \mathrm{NaCl}$ by capillary electrophoresis as reported previously [20]. While slow ester cleavages were observed $\left(\tau_{1 / 2}=69.6 \pm 3.0 \mathrm{~h}\right)$, no redox reactions, as is the case for Zeise's salt in $\mathrm{H}_{2} \mathrm{O}$ [50], were found. The details of the aquation of ASA-buten- $\mathrm{PtCl}_{3}$ remain elusive at this point due to inherent changes in the charge state of the $\mathrm{Pt}^{\mathrm{II}}$ complex that pose a challenge for an observation by mass spectrometry. Initially, $\left[\mathrm{PtCl}_{3}\left(\mathrm{C}_{13} \mathrm{H}_{14} \mathrm{O}_{4}\right)\right]^{-}$was observed at $\mathrm{m} / \mathrm{z} 535.0$ in the negative mode, while the first aquation product $\mathrm{PtCl}_{2}\left(\mathrm{C}_{13} \mathrm{H}_{14} \mathrm{O}_{4}\right)\left(\mathrm{H}_{2} \mathrm{O}\right)$ is neutral and could not be detected. After incubation for $72 \mathrm{~h}$ in water, the appearance of $\left[\mathrm{PtCl}\left(\mathrm{C}_{13} \mathrm{H}_{14} \mathrm{O}_{4}\right)\left(\mathrm{H}_{2} \mathrm{O}\right)_{2}\right]^{+}$at $\mathrm{m} / z, 500.0$ showed that aquation happens at a relevant time scale.

When AT was incubated with ASA-buten- $\mathrm{PtCl}_{3}$, the first adduct observed was $\mathrm{AT}+\mathrm{PtCl}_{2}\left(\mathrm{C}_{13} \mathrm{H}_{14} \mathrm{O}_{4}\right)$ with $\mathrm{m} / z$ 1796.7 (see Fig. 2), where one chlorido ligand has been replaced by
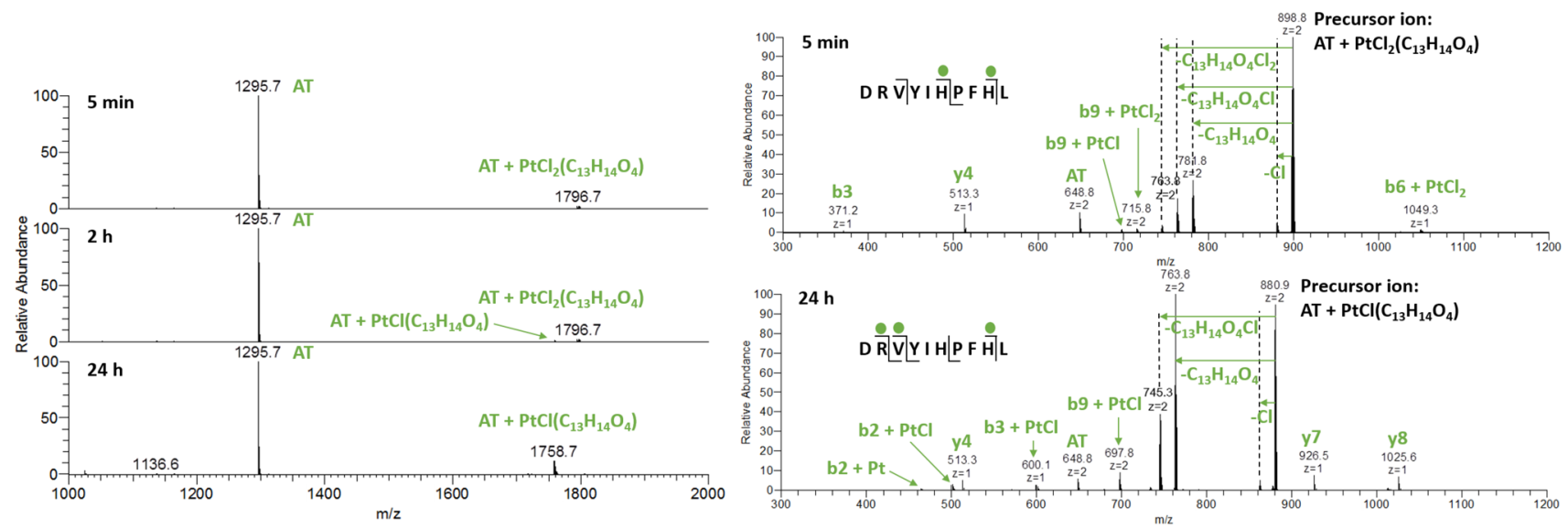

Fig. 2 Left: deconvoluted mass spectra of AT after incubation with ASA-buten- $\mathrm{PtCl}_{3}$ at different points in time. Right: $\mathrm{HCD}$ fragmentation spectra at $15 \%$ NCE of the AT adducts after $5 \mathrm{~min}$ (top) and $24 \mathrm{~h}$ (bottom) 
a suitable donor on the peptide. Presumably, the chlorido ligand trans to the olefin has been exchanged for an aqua ligand, which in turn enabled replacement by a nitrogen of His. After $2 \mathrm{~h}$ of incubation, a second signal with $\mathrm{m} / z, 1758.7$ was detected, which corresponds to $\mathrm{AT}+\mathrm{PtCl}\left(\mathrm{C}_{13} \mathrm{H}_{14} \mathrm{O}_{4}\right)$. After $24 \mathrm{~h}$, this adduct reaches roughly $15 \%$ relative abundance and no further changes were observed in the following 6 days. The ASA-buten moiety remained attached to $\mathrm{Pt}^{\mathrm{II}}$, and no ester bond cleavages were found. Most likely, a stable bidentate coordination between the biomolecule and the $\mathrm{Pt}^{\mathrm{II}}$ center was formed (see structure $\mathbf{1}$ in Fig. 3).

Throughout this study, fragmentation experiments were performed in the form of HCD. The fragmentation energy was increased stepwise to monitor both, the first-bond cleavages (typically $10-15 \%$ NCE) and a maximized number of platinated fragments with higher energies (typically 25-30\% NCE). Data were analyzed with Xcalibur (Thermo) and $\mathrm{Apm}^{2} \mathrm{~s}$ software tool that enables determination of internal metallated fragments on top of the usual $\mathrm{N}$-terminal and C-terminal fragments [43].

HCD fragmentations of the species at $\mathrm{m} / z 1796.7$ with 15\% NCE indicated His6 as first point of attachment for the metal complex. Low fragmentation energy resulted in the loss of the ASA-buten moiety; however, the newly formed bond to $\mathrm{Pt}^{\mathrm{II}}$ was strong enough for a number of platinated fragments to be registered (see Fig. 2). The ions b6 $+\mathrm{PtCl}_{2}$ and the corresponding $\mathrm{y} 4$ suggest that the platinated AT breaks next to the $\mathrm{Pt}^{\mathrm{II}}$ modification site at His6. However, platination at His 9 cannot be excluded. The appearance of a non-platinated b3 fragment is noteworthy, since the picture changes over time. After $24 \mathrm{~h}, \mathrm{HCD}$ fragmentation with $15 \%$ NCE of the species with $\mathrm{m} / \mathrm{z} 1758.7$ resulted in N-terminalplatinated fragments $\left(\mathrm{b} 2 / 3+\mathrm{Pt}(\mathrm{Cl})_{0-1}\right)$ and corresponding non-platinated $\mathrm{y} 7$ and y8 fragments (see Fig. 2). This finding indicates an internal rearrangement of the $\mathrm{PtCl}\left(\mathrm{C}_{13} \mathrm{H}_{14} \mathrm{O}_{4}\right)$ moiety within $24 \mathrm{~h}$ towards the $\mathrm{N}$-terminus, where a

Angiotensin 1 (AT): $\quad$ D R V Y I H P F H L<smiles>CC(=O)NC(=O)[C@@H]1CC(=O)O[P@@](Cl)(C=CCCOC(=O)c2ccccc2OC(C)=O)N1</smiles>

Substance P (Sub P): R P K P Q Q F F G L M

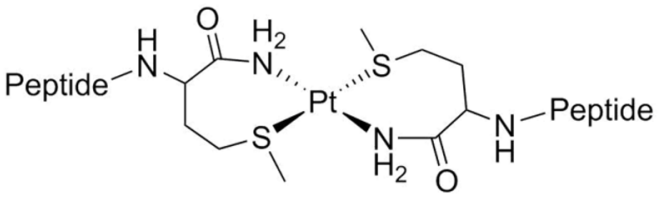

2<smiles>CCONC(=O)C1CC[SH](C)[P](C)(Cl)N1</smiles>

Ubiqutin (UQ):

MQIFVKTLTGKTITLEVEPS

DTIENVKAKIQDKEGIPPDQ

QRLIFAGKQLEDGRTLSDYN I QKESTLHLVLRLRG G

amino acid<smiles>[R]NC(C([R])=O)C(C)OC(C)=O</smiles><smiles>[R]NC(COC(C)=O)C([R])=O</smiles>

Ac-Thr<smiles>[R]NC(CCCCNC(C)=O)C(C)(C)C</smiles><smiles>CCCCOC(=O)NC(=O)C1CCS[P@](O)(C=CCCOC(=O)c2ccccc2OC(C)=O)N1</smiles>

Fig. 3 Sequences of the peptides used in this study with platination sites marked in red and acetylation sites marked in green. Proposed structures (without charges) for the adducts formed upon incubation with ASA-buten- $\mathrm{PtCl}_{3}$ are on the right 
bidentate complexation to Asp can easily be accomplished, as shown in Fig. 3, structure 1. Fragmentation experiments with $30 \%$ NCE produced a number of platinated fragments confirming the $\mathrm{N}$-terminus and both His residues as binding sites (see supplementary material, Table S1).

Experiments with Sub P resulted in a distinctly different picture. Sub P contains one Met amide residue on the C-terminus. This offers the possibility to form a bidentate coordination to $\mathrm{Pt}^{\mathrm{II}}$ via sulfur and either the $\mathrm{C}$-terminal amide nitrogen or the first backbone nitrogen resulting in a 6- or 7-membered ring, respectively. The measurement after 5 min of incubation showed a high abundant adduct with $\mathrm{m} / \mathrm{z} 2961.4$ (see Fig. 4) that corresponds to the dimer (Sub $\mathrm{P})_{2} \mathrm{PtCl}_{2}$. This finding can be rationalized by a substitution of the trans chlorido ligand by the Met1 1 thioether. Sulfur has a strong trans labilizing effect and, consequently, the bond to the olefin is weakened upon coordination. Another entity of Sub $\mathrm{P}$ is able to bind to the $\mathrm{Pt}^{\mathrm{II}}$ center, while the organic moiety is released. The two chlorido ligands remain attached at first, but some release is observed over time. The species with $\mathrm{m} / \mathrm{z} 2887.4$ resembles a Sub P dimer that is crosslinked by $\mathrm{Pt}^{\mathrm{II}}$ and presumably looks like compound $\mathbf{2}$ in Fig. 3.

$\mathrm{HCD}$ experiments of the dimer (Sub $\mathrm{P})_{2} \mathrm{PtCl}_{2}$ at $15 \%$ $\mathrm{NCE}$ resulted mainly in the loss of chlorido ligands and $\mathrm{NH}_{3}$ from side chains (see Fig. 5). The formation of free Sub P at $\mathrm{m} / \mathrm{z} 674.4$ and Sub $\mathrm{P}-\mathrm{NH}_{3}$ at $\mathrm{m} / z 665.9$ and $\mathrm{m} / \mathrm{z}$ 444.2, in charge states 2 and 3, respectively, confirms the dissociation of the dimer. Interestingly, b10 can be seen in comparatively
Fig. 4 Deconvoluted mass spectra of Sub $\mathrm{P}$ after incubation with ASA-buten- $-\mathrm{PtCl}_{3}$

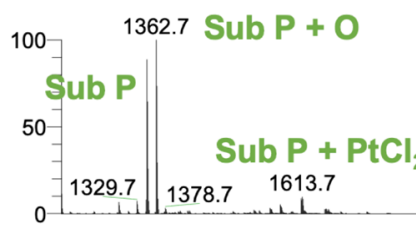

100 _ 1346

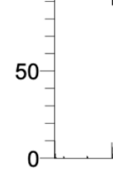

100

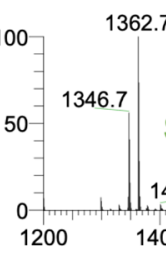

\section{8}

1362.7

1575.7
Sub $\mathrm{P}+\mathrm{PtCl}$

1378.7 ...L.L. $1657.7 \quad 1846.8$

\section{$5 \mathrm{~min}$}

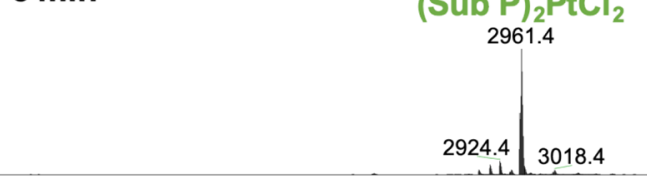

$2 \mathrm{~h}$

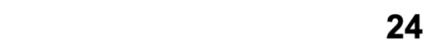

$24 \mathrm{~h}$

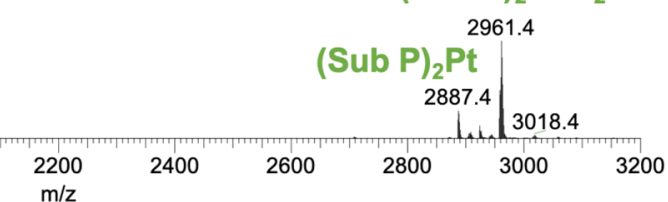

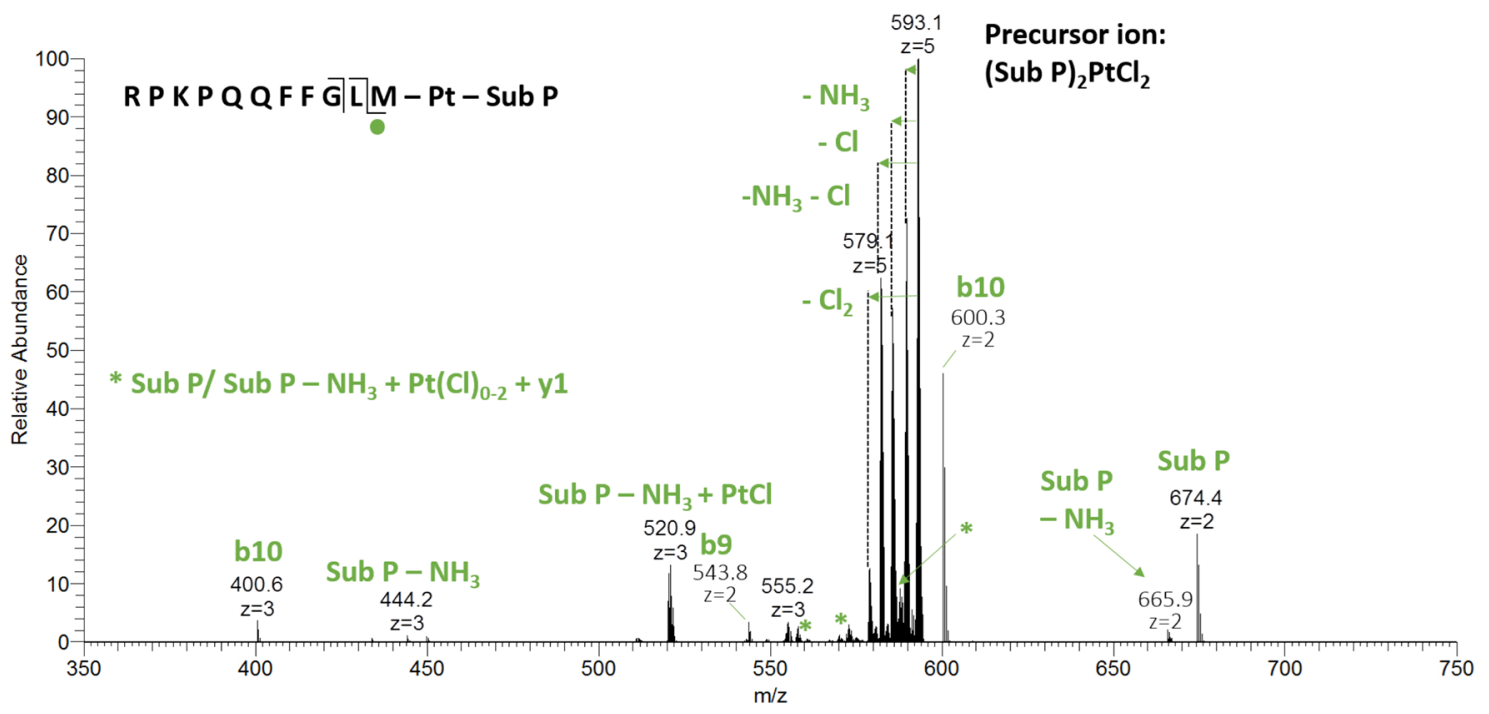

Fig. $5 \mathrm{HCD}$ fragmentation spectrum at $10 \% \mathrm{NCE}$ of the dimer $(\mathrm{Sub} \mathrm{P})_{2} \mathrm{PtCl}_{2}$ 
high abundance, which enabled the assignment of some corresponding fragments that still contain the $\mathrm{Pt}^{\mathrm{II}}$ crosslink. These are the triply charged species $\mathrm{Sub} \mathrm{P}+\mathrm{PtCl}_{2}+\mathrm{y} 1$ at $\mathrm{m} / z$ 587.9, Sub $\mathrm{P}-\mathrm{NH}_{3}+\mathrm{PtCl}+\mathrm{y} 1$ at $\mathrm{m} / z$ 570.2 and Sub $\mathrm{P}-\mathrm{NH}_{3}+\mathrm{Pt}+\mathrm{y} 1$ (see supplementary material, Figure S2 for isotopic distributions). Higher fragmentation energies primarily led to the loss of the $\mathrm{Pt}^{\mathrm{II}}$ moiety and no small platinated fragments could be detected. However, the positioning of $\mathrm{Pt}^{\mathrm{II}}$ on Met is quite certain based on the data observed and in accordance with HSAB theory. A full list of fragments can be found in the supplementary material (Table S2).

Higher oligomers up to a tetramer of Sub P were observed at low abundance (see Table 1). Also, the MS signal was in general much worse than in the experiments with AT and declined over time. These observations point to $\mathrm{Pt}^{\mathrm{II}}$-induced

Table 1 Adducts and oligomers of Sub $\mathrm{P}$ after $48 \mathrm{~h}$ incubation with ASA-buten- $\mathrm{PtCl}_{3}$

\begin{tabular}{lllc}
\hline Species & $m_{\text {exp }}$ & $m_{\text {calc }}$ & Error (ppm) \\
\hline Sub P & 1346.7311 & 1346.7276 & -2.60 \\
Sub P + Pt & 1539.6807 & 1539.6825 & 1.17 \\
Sub P $+\mathrm{PtCl}$ & 1575.6577 & 1575.6591 & 0.89 \\
Sub P $+\mathrm{PtCl}$ & 1613.6343 & 1613.6379 & 2.23 \\
$(\text { Sub P })_{2} \mathrm{Pt}$ & 2887.4143 & 2887.4131 & -0.42 \\
$(\text { Sub P })_{2} \mathrm{PtCl}$ & 2924.3925 & 2924.3910 & -0.51 \\
$(\text { Sub P })_{2} \mathrm{PtCl}_{2}$ & 2961.3670 & 2961.3680 & 0.34 \\
$(\text { Sub P })_{3} \mathrm{Pt}_{2} \mathrm{Cl}_{2}$ & 4501.0494 & 4501.0387 & -2.38 \\
$(\text { Sub P })_{3} \mathrm{Pt}_{2} \mathrm{Cl}_{4}$ & 4575.0009 & 4574.9988 & -0.46 \\
$(\text { Sub P })_{4} \mathrm{Pt}_{2} \mathrm{Cl}_{3}$ & 5886.7444 & 5886.7533 & 1.51 \\
$(\text { Sub P })_{4} \mathrm{Pt}_{3} \mathrm{Cl}_{6}$ & 6188.6440 & 6188.6297 & -2.31 \\
\hline
\end{tabular}

peptide aggregation and crosslinking. For comparison, Sub $\mathrm{P}$ was incubated with ASA-buten- $\mathrm{PtCl}_{3}$ at equimolar ratio (see supplementary material, Fig. S1). In this case, the signal-to-noise ratio was better. The main adduct observed was Sub $\mathrm{P}+\mathrm{PtCl}_{2}$, which lost its chlorido ligands over time. The $\mathrm{Pt}^{\mathrm{II}}$-coordinated Sub P dimer appeared at significantly lower abundance, and no higher oligomers were observed. Similar findings were reported by Merlino et al. [51], who investigated the formation of cisplatin interprotein crosslinks and platinated oligomers of RNase A.

Neither AT nor Sub P were acetylated by the ASA moiety.

UQ is the largest peptide in this study with 76 amino acids, a Met residue at the N-terminus, His68, and some weaker binding partners (free $-\mathrm{OH}$ and $-\mathrm{COOH}$ residues) for $\mathrm{Pt}^{\mathrm{II}}$ that have been identified before [43].

Upon incubation with ASA-buten-PtCl ${ }_{3}$, two sets of adducts appeared after $5 \mathrm{~min}$, one with the $\mathrm{PtCl}_{0-2}\left(\mathrm{C}_{13} \mathrm{H}_{14} \mathrm{O}_{4}\right)$ moiety attached and the other with $\mathrm{PtCl}_{0-2}$ only (see Fig. 6). The latter can be explained by an attack of the Met sulfur trans to the olefin and subsequent release of the organic ligand (see structure 3 in Fig. 3). The binding site of $\mathrm{Pt}^{\mathrm{II}}$ is confirmed by the appearance of small $\mathrm{Pt}^{\mathrm{II}}$ containing fragments a3 + Pt $(m / z$ 540.2) and b4 $+\mathrm{Pt}(\mathrm{m} / z$ 713.2)

As observed for both UQ and Sub P, the trans labilizing effect of the thioether in Met caused fast release of the organic moiety. Hence, the retention of the ASA-buten moiety in the second set of signals can only be rationalized by coordination of a nitrogen (or less likely oxygen) ligand trans to the olefin. HCD fragmentation of the precursor $m / z 750.3\left(z=12, \mathrm{UQ}+\operatorname{Pt}\left(\mathrm{C}_{13} \mathrm{H}_{14} \mathrm{O}_{4}\right)\right)$ with low energy shows two corresponding ions b18+ $\mathrm{Pt}\left(\mathrm{C}_{13} \mathrm{H}_{14} \mathrm{O}_{4}\right)$ and y58 (see Fig. 7). Besides the N-terminal Met, there are several

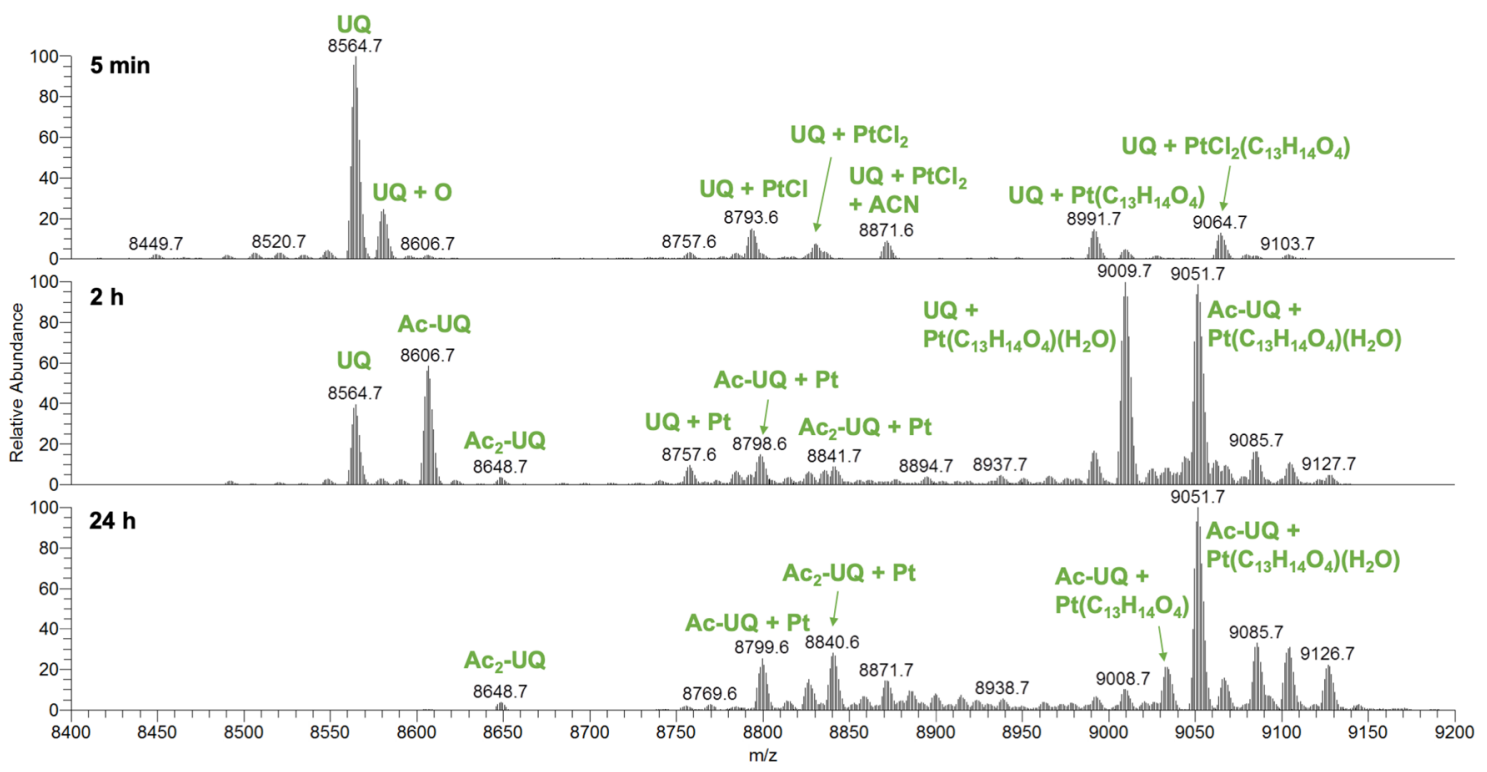

Fig. 6 Deconvoluted mass spectra of UQ after incubation with ASA-buten-PtCl 3 
nitrogen and oxygen donors in the b18 fragment that may serve as binding partners; however, further fragmentations with $25 \%$ NCE point to the N-terminal Met as binding site. Fragments $a 3 / 4+\mathrm{Pt}$ and b3/4 + Pt were detected (see supplementary material, Table S4 for a full list of fragments). One possible explanation for the retention of the ASA-buten moiety in this case is the formation of isomer $\mathbf{4}$ depicted in Fig. 3, where the N-terminal nitrogen is in the trans position to the olefin and sulfur is cis. After $24 \mathrm{~h}$ of incubation, HCD fragmentation of the precursor $m / z 1133.1[z=8$, Ac-UQ + $\mathrm{Pt}\left(\mathrm{C}_{13} \mathrm{H}_{14} \mathrm{O}_{4}\right)\left(\mathrm{H}_{2} \mathrm{O}\right)$, see below] yielded the interesting fragment $\mathrm{b} 1+\operatorname{Pt}\left(\mathrm{C}_{13} \mathrm{H}_{14} \mathrm{O}_{4}\right)$ and the corresponding acetylated y75 fragment (see Fig. 7). This is further evidence for the formation of isomer 4.

Importantly, UQ was acetylated by ASA-buten- $\mathrm{PtCl}_{3}$ as indicated by a high abundant signal for Ac-UQ with $\mathrm{m} / \mathrm{z}$
8606.7 and $\mathrm{Ac}_{2}$-UQ with $\mathrm{m} / \mathrm{z} 8648.7$ after $2 \mathrm{~h}$. These signals have almost disappeared after $24 \mathrm{~h}$, and instead, UQ is found to be both, acetylated and platinated (see Fig. 6). To the best of our knowledge, this is the first example of two different chemical modifications on a single peptide by an NSAID metal complex. After $24 \mathrm{~h}$, Ac-UQ $+\mathrm{Pt}\left(\mathrm{C}_{13} \mathrm{H}_{14} \mathrm{O}_{4}\right)\left(\mathrm{H}_{2} \mathrm{O}\right)$ is the most abundant species and no further changes were observed in the next 6 days. Control experiments with ASA did not show any acetylations (see supplementary material, Fig. S3). HCD fragmentations revealed Lys6, Thr7, Thr14, Ser20, Thr22, Lys27, Lys29, Thr55, Ser57, Ser65, and Thr66 as possible acetylation sites (see Table 2 and Fig. 3). Clearly acetylation happened in a non-specific fashion.
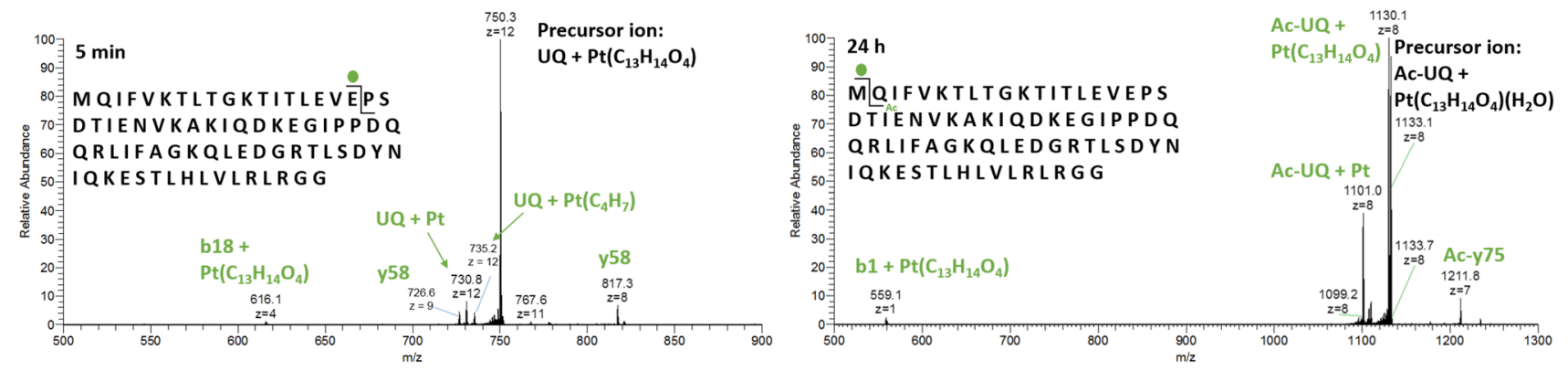

Fig. $7 \mathrm{HCD}$ fragmentation spectra at 15\% NCE of UQ adducts

Table 2 Acetylated fragments of UQ smaller than ten amino acids; precursor ion $\mathrm{m} / \mathrm{z} 1133.1$ $\left[z=8, \mathrm{Ac}-\mathrm{UQ}+\mathrm{Pt}\left(\mathrm{C}_{13} \mathrm{H}_{14} \mathrm{O}_{4}\right)\right.$ $\left(\mathrm{H}_{2} \mathrm{O}\right)$ ]

\begin{tabular}{|c|c|c|c|c|c|}
\hline Acetylated fragment & Amino acids & $m_{\text {calc }}$ & $m_{\exp }$ & Similarity & Error (ppm) \\
\hline a20y58 & Pro-Ser(Ac) & 199.1083 & 199.1077 & 88.4 & 2.39 \\
\hline a29y49 & Ala-Lys(Ac) & 214.1556 & 214.1550 & 76.1 & 2.30 \\
\hline a28y50 & (Ac)Lys-Ala & 214.1556 & 214.1550 & 76.1 & 2.30 \\
\hline a57y21 & Leu-Ser(Ac) & 215.1396 & 215.1390 & 74.4 & 1.87 \\
\hline b29y49 & Ala-Lys(Ac) & 242.1505 & 242.1499 & 78.5 & 2.92 \\
\hline b28y50 & (Ac)Lys-Ala & 242.1505 & 242.1499 & 78.5 & 2.92 \\
\hline b57y21 & Leu-Ser(Ac) & 243.1345 & 243.1339 & 78.9 & 1.97 \\
\hline b27y51, b6y72 & Val-Lys(Ac) & 270.1818 & 270.1812 & 76.7 & 2.21 \\
\hline a67y12 & Ser-Thr-Leu ${ }^{a}$ & 316.1872 & 316.1867 & 88.0 & 2.67 \\
\hline a57y 22 & Thr-Leu-Ser ${ }^{\mathrm{a}}$ & 316.1872 & 316.1867 & 88.0 & 2.67 \\
\hline b67y 12 & Ser-Thr-Leu ${ }^{a}$ & 344.1822 & 344.1816 & 88.0 & 2.48 \\
\hline b57y 22 & Thr-Leu-Ser ${ }^{\mathrm{a}}$ & 344.1822 & 344.1816 & 88.0 & 2.48 \\
\hline b58y21 & Leu-Ser(Ac)-Asp & 358.1614 & 358.1609 & 79.2 & 2.78 \\
\hline b7y72 & Val-Lys-Thr ${ }^{\mathrm{a}}$ & 371.2294 & 371.2289 & 81.7 & 2.31 \\
\hline b6y73 & Phe-Val-Lys(Ac) & 417.2502 & 417.2496 & 85.0 & 2.39 \\
\hline a17y63 & Thr(Ac)-Leu-Glu-Val & 457.2662 & 457.2657 & 75.5 & 2.55 \\
\hline b31y49 & Ala-Lys(Ac)-Ile-Gln & 483.2931 & 483.2926 & 72.5 & 3.22 \\
\hline a22y60 & Val-Glu-Pro-Ser-Asp-Thr ${ }^{\mathrm{a}}$ & 643.2939 & 643.2933 & 79.4 & 2.80 \\
\hline b6 & Met-Gln-Ile-Phe-Val-Lys(Ac) & 789.4333 & 789.4328 & 78.1 & 3.11 \\
\hline
\end{tabular}

${ }^{\mathrm{a}}$ Two possible acetylation sites in the sequence 


\section{Conclusions}

Molecular interactions of the NSAID metal complex ASA-buten-PtCl ${ }_{3}$ with three model peptides were investigated by top-down mass spectrometry. The $\mathrm{Pt}^{\mathrm{II}}$ complex formed different adducts depending on the amino acids available for binding. Trans labilizing effects played a crucial role in the outcome of the reaction. Depending on the type of ligand that coordinated trans to the olefin, the organic moiety was released quickly or retained for the duration of the experiment, i.e. 7 days. Based on MS results, we conclude that within $24 \mathrm{~h}, \mathrm{Pt}^{\mathrm{II}}$ is coordinated in a bidentate fashion in all cases. Dimer formation and oligomerization were observed in the case of Sub P. Most importantly, we could prove that the combination of an NSAID with a metal complex truly led to a compound that can add two different chemical modifications to a peptide at the same time. Ubiquitin was found to be both acetylated and platinated by ASA-buten- $\mathrm{PtCl}_{3}$. Control experiments with ASA did not show any acetylation.

Increasing our general understanding of the interactions between metal complexes and biomolecules is pivotal in the development of better metallodrug candidates.

Acknowledgements Open access funding provided by Austrian Science Fund (FWF). Thanks to Alexander Weninger for the synthesis of ASA-buten-PtCl ${ }_{3}$. The support of the FWF (Project number P31166) is gratefully acknowledged.

\section{Compliance with ethical standards}

Conflict of interest The authors declare that they have no conflict of interest.

Open Access This article is licensed under a Creative Commons Attribution 4.0 International License, which permits use, sharing, adaptation, distribution and reproduction in any medium or format, as long as you give appropriate credit to the original author(s) and the source, provide a link to the Creative Commons licence, and indicate if changes were made. The images or other third party material in this article are included in the article's Creative Commons licence, unless indicated otherwise in a credit line to the material. If material is not included in the article's Creative Commons licence and your intended use is not permitted by statutory regulation or exceeds the permitted use, you will need to obtain permission directly from the copyright holder. To view a copy of this licence, visit http://creativecommons.org/licenses/by/4.0/.

\section{References}

1. Banti CN, Hadjikakou SK (2016) Eur J Inorg Chem 19:30483071. https://doi.org/10.1002/ejic.201501480

2. Hardman JG, Limbird LE (1996) Goodman and Gilman's the pharmacological basis of therapeutics, 9th edn. McGraw-Hill, New York
3. Ashraf A, Aman F, Movassaghi S, Zafar A, Kubanik M, Siddiqui WA, Reynisson J, Sohnel T, Jamieson SMF, Hanif M, Hartinger CG (2019) Organometallics 38:361-374. https://doi. org/10.1021/acs.organomet.8b00751

4. Zheng P, Eskandari A, Lu C, Laws K, Aldous L, Suntharalingam K (2019) Dalton Trans 48:5892-5896. https://doi.org/10.1039/ c8dt04706e

5. Srivastava P, Mishra R, Verma M, Sivakumar S, Patra AK (2019) Polyhedron 172:132-140. https://doi.org/10.1016/j. poly.2019.04.009

6. Lakshman TR, Deb J, Ghosh I, Sarkar S, Paine TK (2019) Inorg Chim Acta 486:663-668. https://doi.org/10.1016/j. ica.2018.11.025

7. Skiba J, Kowalczyk A, Stączek P, Bernaś T, Trzybiński D, Woźniak K, Schatzschneider U, Czerwieniec R, Kowalski K (2019) New J Chem 43:573-583. https://doi.org/10.1039/C8NJ0 $5494 \mathrm{~K}$

8. Mandal P, Kundu BK, Vyas K, Sabu V, Helen A, Dhankhar SS, Nagaraja CM, Bhattacherjee D, Bhabake KP, Mukhopadhyay S (2018) Dalton Trans 47:517-527. https://doi.org/10.1039/c7dt0 $3637 \mathrm{j}$

9. Hanif-Ur-Rehman PW, Freitas TE, Gomes RN, Colquhoun A, de Oliveira Silva D (2016) J Inorg Biochem 165:181-191. https:// doi.org/10.1016/j.jinorgbio.2016.10.003

10. Păunescu E, McArthur S, Soudani M, Scopelliti R, Dyson PJ (2016) Inorg Chem 55:1788-1808. https://doi.org/10.1021/acs. inorgchem.5b02690

11. Boodram JN, Mcgregor IJ, Bruno PM, Cressey PB, Hemann MT, Suntharalingam K (2016) Angew Chem Int Ed 128:2895-2900. https://doi.org/10.1002/ange.201510443

12. Wu XW, Zheng Y, Wang FX, Cao JJ, Zhang H, Zhang DY, Tan CP, Ji LN, Mao ZW (2019) Chem Eur J 25:7012-7022. https:// doi.org/10.1002/chem.201900851

13. Cheng Q, Shi H, Wang H, Wang J, Liu Y (2016) Metallomics 8:672-678. https://doi.org/10.1039/C6MT00066E

14. Banti CN, Papatriantafyllopoulou C, Tasiopoulos AJ, Hadjikakou SK (2018) Eur J Med Chem 143:1687-1701. https://doi. org/10.1016/j.ejmech.2017.10.067

15. Rubner G, Bensdorf K, Wellner A, Bergemann S, Gust R (2011) Arch Pharm Chem Life Sci 344:684-688. https://doi.org/10.1002/ ardp. 201000382

16. Rubner G, Bensdorf K, Wellner A, Bergemann S, Ott I, Gust R (2010) Eur J Med Chem 45:5157-5163. https://doi.org/10.1016/j. ejmech.2010.08.028

17. Rubner G, Bensdorf K, Wellner A, Kircher B, Bergemann S, Ott I, Gust R (2010) J Med Chem 53:6889-6898. https://doi. org/10.1021/jm101019j

18. Ott I, Kircher B, Bagowski CP, Vlecken DHW, Ott EB, Will J, Bensdorf K, Sheldrick WS, Gust R (2009) Angew Chem Int Ed 48:1160-1163. https://doi.org/10.1002/anie.200803347

19. Meieranz S, Stefanopoulou M, Rubner G, Bensdorf K, Kubutat D, Sheldrick WS, Gust R (2015) Angew Chem Int Ed 54:2834-2837. https://doi.org/10.1002/anie.201410357

20. Weninger A, Baecker D, Obermoser V, Egger D, Wurst K, Gust R (2018) Int J Mol Sci 19:1612-1628. https://doi.org/10.3390/ijms1 9061612

21. Meier SM, Tsybin YO, Dyson PJ, Keppler BK, Hartinger CG (2011) Anal Bioanal Chem 402:2655-2662. https://doi. org/10.1007/s00216-011-5523-0

22. Wootton CA, Millett AJ, Lopez-Clavijo AF, Chiu CKC, Barrow MP, Clarkson GJ, Sadler PJ, O'Connor PB (2019) Analyst 144:1575-1581. https://doi.org/10.1039/c8an02094a

23. Xu Z, Shaw JB, Brodbelt JS (2013) J Am Soc Mass Spectrom 24:265-273. https://doi.org/10.1007/s13361-012-0532-6 
24. Wenzel M, Casini A (2017) Coord Chem Rev 352:432-460. https ://doi.org/10.1016/j.ccr.2017.02.012

25. Hartinger CG, Groessl M, Meier SM, Casini A, Dyson PJ (2013) Chem Soc Rev 42:6186-6199. https://doi.org/10.1039/c3cs3 $5532 \mathrm{~b}$

26. Wills RH, Habtemariam A, Lopez-Clavijo AF, Barrow MP, Sadler PJ, O'Connor PB (2014) J Am Soc Mass Spectrom 25:662-672. https://doi.org/10.1007/s13361-013-0819-2

27. Williams JP, Brown JM, Campuzano I, Sadler PJ (2010) Chem Commun (Camb) 46:5458-5460. https://doi.org/10.1039/c0cc0 0358a

28. Li H, Snelling JR, Barrow MP, Scrivens JH, Sadler PJ, O'Connor PB (2014) J Am Soc Mass Spectrom 25:1217-1227. https://doi. org/10.1007/s13361-014-0877-0

29. Li H, Lin TY, Van Orden SL, Zhao Y, Barrow MP, Pizarro AM, Qi Y, Sadler PJ, O’Connor PB (2011) Anal Chem 83:9507-9515. https://doi.org/10.1021/ac202267g

30. Qi Y, Liu Z, Li H, Sadler PJ, O’Connor PB (2013) Rapid Commun Mass Spectrom 27:2028-2032. https://doi.org/10.1002/rcm.6643

31. Egger AE, Hartinger CG, Hamidane HB, Tsybin YO, Keppler BK, Dyson PJ (2008) Inorg Chem 47:10626-10633. https://doi. org/10.1021/ic801371r

32. Groessl M, Tsybin YO, Hartinger CG, Keppler BK, Dyson PJ (2010) J Biol Inorg Chem 15:677-688. https://doi.org/10.1007/ s00775-010-0635-0

33. Wootton CA, Sanchez-Cano C, Liu HK, Barrow MP, Sadler PJ, O'Connor PB (2015) Dalton Trans 44:3624-3632. https://doi. org/10.1039/c4dt03819c

34. Burstyn JN, Heiger-Bernays WJ, Cohen SM, Lippard SJ (2000) Nucleic Acids Res 28:4237-4243. https://doi.org/10.1093/ nar/28.21.4237

35. DeConti R, Toftness B, Lange R, Creasez W (1973) Cancer Res 33:1310-1315

36. Oun R, Moussa YE, Wheate NJ (2018) Dalton Trans 47:66456653. https://doi.org/10.1039/c8dt00838h

37. Li H, Zhao Y, Phillips HIA, Qi Y, Lin TY, Sadler PJ, O'Connor PB (2011) Anal Chem 83:5369-5376. https://doi.org/10.1021/ ac200861k
38. Messori L, Marzo T, Merlino A (2015) J Inorg Biochem 153:136142. https://doi.org/10.1016/j.jinorgbio.2015.07.011

39. Liu H, Zhang N, Cui M, Liu Z, Liu S (2016) Int J Mass Spectrom 409:59-66. https://doi.org/10.1016/j.ijms.2016.09.017

40. Li J, Yue L, Liu Y, Yin X, Yin Q, Pan Y, Yang L (2016) Amino Acids 48:1033-1043. https://doi.org/10.1007/s00726-015-2159-y

41. Hartinger CG, Tsybin YO, Fuchser J, Dyson PJ (2008) Inorg Chem 47:17-19. https://doi.org/10.1021/ic702236m

42. Williams JP, Phillips HIA, Campuzano I, Sadler PJ (2010) J Am Soc Mass Spectrom 21:1097-1106. https://doi.org/10.1016/j. jasms.2010.02.012

43. Lee RFS, Menin L, Patiny L, Ortiz D, Dyson PJ (2017) Anal Chem 89:11985-11989. https://doi.org/10.1021/acs.analchem.7b02211

44. Wexselblatt E, Yavin E, Gibson D (2012) Inorg Chim Acta 393:75-83. https://doi.org/10.1016/j.ica.2012.07.013

45. Cziferszky M, Gust R (2018) J Inorg Biochem 189:53-57. https ://doi.org/10.1016/j.jinorgbio.2018.09.003

46. Scholz M, Kaluđerović GN, Kommera H, Paschke R, Will J, Sheldrick WS, Hey-Hawkins E (2011) Eur J Med Chem 46:11311139. https://doi.org/10.1016/j.ejmech.2011.01.030

47. Nazarov AA, Meier SM, Zava O, Nosova YN, Milaeva ER, Hartinger CG, Dyson PJ (2015) Dalton Trans 44:3614-3623. https ://doi.org/10.1039/c4dt02764g

48. Bresolo F, Johnson RC (1964) Coordination chemistry. WA Benjamin Inc, New York

49. Lokken SJ, Martin DS Jr (1963) Inorg Chem 2:562-568. https:// doi.org/10.1021/ic50007a034

50. Joy JR, Orchin M (1960) Z Anorg Allg Chem 305:236-240

51. Picone D, Donnarumma F, Ferraro G, Gotte G, Fagagnini A, Butera G, Donadelli M, Merlino A (2017) J Inorg Biochem 173:105-112. https://doi.org/10.1016/j.jinorgbio.2017.05.005

Publisher's Note Springer Nature remains neutral with regard to jurisdictional claims in published maps and institutional affiliations. 